\title{
Faktor-Faktor yang Berhubungan dengan Pemberian Makanan Pendamping ASI Dini
}

\author{
Eko Heryanto \\ Program Studi S.1 Kesehatan Masyarakat STIKES Al-Ma'arif Baturaja \\ Email: ekoheryanto@ymail.com
}

\begin{abstract}
ABSTRAK
Kejadian infeksi saluran pencernaan dan pernafasan merupakan salah satu penyebab tingginya angka kematian bayi di Indonesia yang disebabkan oleh pemberian Makanan Pendamping ASI (MPASI) dini. Pemberian MPASI dini pada bayi dengan ASI parsial lebih beresiko terserang diare, batuk-pilek, dan panas dibandingkan bayi dengan ASI predominan. Data yang diambil tahun 2016 di Desa Negeri Agung tercatat kasus bayi sudah di beri MPASI yaitu sebesar 42 bayi (45,65\%) dari 92 bayi. Penelitian ini bertujuan untuk mengetahui faktor-faktor yang berhubungan dengan pemberian MPASI dini. Penelitian ini merupakan penelitian cross sectional dengan populasi seluruh ibu yang mempunyai bayi berusia 7-12 bulan di Desa Negeri Agung pada periode Januari Maret 2017 yang berjumlah 51 orang. Analisis statistik yang digunakan adalah uji chi square. Data penelitian menunjukkan sebanyak 5,1\% responden memberikan MPASI dini kepada bayinya, 51\% responden memiliki pengetahuan yang baik tentang MPASI, 62,7\% responden dengan kecukupan ASI, 52,9\% responden dengan kategori tidak bekerja dan sebanyak 54,9\% responden mendapatkan dukungan dari keluarga. Hasil analisis menunjukkan korelasi antara pemberian MPASI dini dengan pengetahuan ( $p$ value 0,017), kecukupan ASI ( $p$ value 0,001), pekerjaan ( $p$ value 0,001) dan dukungan keluarga ( $p$ value 0,001). Petugas kesehatan dapat meningkatkan perhatian ibu menyusui terhadap pemberian ASI ekslusif dengan memberikan penyuluhan atau pendidikan kesehatan mengenai manfaat dan pentingnya ASI ekslusif.
\end{abstract}

Kata Kunci: Pengetahuan, Kecukupan ASI, pekerjaan, Dukungan Keluarga, MPASI Dini

\section{RELATED FACTORS WITH PROVIDING EARLY WEANING FOOD}

\begin{abstract}
The occurrence of gastrointestinal and respiratory infections caused by early early weaning food (MPASI) is one factor of the high infant mortality rate in Indonesia. The administration of early MPASI in infants with partial breast milk is more at risk for diarrhea, influenza, and fever than infants with predominant breast milk. Data taken in 2016 in the village of Negeri Agung recorded cases of infants have been given MPASI that amounted to 42 babies (45.65\%) of 92 babies. This study aims to determine the factors associated with the provision of early MPASI. This study is a cross sectional study with a population of all mothers who have babies aged 7-12 months in Desa Negeri Agung in period January - March 2017 which amounted to 51 people. Statistical analysis used was chi square test. The data showed that 5.1\% of respondents gave early MPASI to their babies, 51\% of respondents had good knowledge about MPASI, 62.7\% of respondents were sufficiently breastfeed, 52.9\% of respondents were not working and 54.9\% get support from family. The result of analysis showed correlation between early MPASI with knowledge ( $p$ value 0,017), breastfeed sufficiency ( $p$ value 0,000), occupation ( $p$ value 0,001) and family support (p value 0,000). Healthcare officer may increase attention of breastfeeding mothers to exclusive breastfeeding by providing education or health education on the benefits and importance of exclusive breastfeeding.
\end{abstract}

Keywords: Knowledge, Breastfeeding Sufficiency, Occupation, Family Support, Early Weaning Food

How to Cite: Heryanto, Eko. (2017). Faktor-Faktor yang Berhubungan dengan Pemberian Makanan Pendamping ASI Dini. Jurnal Aisyah: Jurnal Ilmu Kesehatan. 2 (2), 141 - 152. 


\section{PENDAHULUAN}

Usia 0 - 24 bulan merupakan masa pertumbuhan dan perkembangan yang pesat, sehingga kerap diistilahkan sebagai periode emas sekaligus periode kritis. Periode emas dapat diwujudkan apabila pada masa ini bayi dan anak memperoleh asupan gizi yang sesuai untuk tumbuh kembang optimal. (Depkes RI, 2010).

Untuk mencapai tumbuh kembang optimal, di dalam Global Strategy for Infant and Young Child Feeding, World Health Organization (WHO) merekomendasikan empat hal penting yang harus dilakukan yaitu; pertama memberikan air susu ibu kepada bayi segera dalam waktu 30 menit setelah bayi lahir, kedua memberikan hanya air susu ibu (ASI) saja atau pemberian ASI secara eksklusif sejak lahir sampai bayi berusia 6 bulan, ketiga memberikan makanan pendamping air susu ibu (MPASI) sejak bayi berusia 6 bulan sampai 24 bulan, dan keempat meneruskan pemberian ASI sampai anak berusia 24 bulan atau lebih (Depkes RI, 2012)

Secara umum praktik pemberian ASI eksklusif masih rendah dari target pencapaian. Hanya $35 \%$ bayi di dunia dan $39 \%$ di Negara berkembang yang mendapatkan ASI eksklusif. Rata-rata pemberian ASI eksklusif di wilayah Asia Tenggara hanya 45\%. UNICEF menyimpulkan, cakupan ASI eksklusif 6 bulan di Indonesia masih jauh dari rata-rata dunia yaitu 38\% (Helmi \& Lupiana, 2011).

Kejadian infeksi saluran pencernaan dan pernafasan akibat pemberian MP-ASI dini merupakan salah satu penyebab tingginya angka kematian bayi di Indonesia. Dampak negatif dari pemberian MP-ASI dini tersebut sesuai dengan riset yang dilakukan oleh Pusat Penelitian dan Pengembangan Gizi dan Makanan diketahui, bayi ASI parsial lebih banyak yang terserang diare, batuk-pilek, dan panas daripada bayi ASI predominan.
Data yang diambil dari Dinas Kesehatan Kabupaten OKU Selatan tahun 2014 bayi yang sudah diberikan MP-ASI dini sebesar 4.776 bayi $(42,78 \%)$ dari 11.164 bayi, kemudian pada tahun 2015 bayi yang sudah diberikan MP-ASI dini menjadi 4.809 bayi (42,93\%) dari 11.201 bayi dan pada tahun 2016 bayi yang sudah diberikan MP-ASI dini menjadi sebesar 4.712 bayi $(41,89 \%)$ dari 11.248 bayi (Dinkes OKU Selatan, 2016).

Berdasarkan data yang diambil dari UPTD Puskesmas Buay Sandang Aji tahun 2014 bayi yang sudah diberikan MP-ASI dini sebesar 278 bayi $(44,33 \%)$ dari 627 bayi, pada tahun 2015 menjadi sebesar 264 bayi $(43,06 \%)$ dari 613 bayi dan pada tahun 2016 menjadi 281 bayi $(44,46 \%)$ dari 632 bayi (Puskesmas Buay Sandang Aji, 2015).

Desa Negeri Agung yang merupakan salah satu dari 16 desa yang berada di Wilayah Kerja UPTD Puskesmas Buay Sandang Aji pada tahun 2014 bayi yang sudah diberikan MP-ASI dini sebesar 51 bayi (46, 78\%) dari 109 bayi, pada tahun 2015 menjadi sebesar 48 bayi $(45,71 \%)$ dari 105 bayi dan pada tahun 2016 Desa Negeri Agung menempati urutan ke 2 dengan kasus bayi sudah di beri MP-ASI yaitu sebesar sebesar 42 bayi $(45,65 \%)$ dari 92 bayi.

Banyak faktor yang berhubungan dengan pemberian MP-ASI dini oleh ibu. Faktorfaktor tersebut meliputi pengetahuan, kesehatan dan pekerjaan ibu, iklan MP-ASI, petugas kesehatan, budaya dan sosial ekonomi. Pengetahuan ibu yang masih kurang terhadap manfaat pemberian ASI eksklusif sangat erat kaitannya dengan pemberian MP-ASI dini. Faktor penghambat keberlanjutan pemberian ASI adalah pengetahuan dan keyakinan ibu bahwa bayi tidak akan cukup memperoleh zat gizi jika hanya diberi ASI sampai umur 6 bulan.

Berdasarkan latar belakang diatas, maka peneliti melakukan melakukan penelitian 
dengan tujuan mengkaji faktor-faktor yang berhubungan dengan pemberian MPASI.

\section{METODE PENELITIAN}

Desain penelitian yang digunakan adalah desain penelitian Crossectional, dimana variabel independen dan variabel dependen diobservasi sekaligus pada saat yang sama.

Dalam penelitian ini yang dimaksud dengan variabel independen adalah pengetahuan ibu, pekerjaan ibu, kecukupan ASI dan dukungan keluarga, sedangkan yang dimaksud dengan variabel dependen adalah pemberian MP-ASI dini. Populasi penelitian adalah seluruh ibu yang mempunyai bayi berusia $7-12$ bulan. Sampel diambil total populasi periode bulan
Agustus - Oktober 2017 yang berjumlah 51 orang. Lokasi penelitian di Desa Negeri Agung Wilayah Kerja UPTD Puskesmas Buay Sandang Aji Kabupaten OKU Selatan. Analisa yang digunakan menggunakan analisa univariat yaitu dilakukan untuk menjelaskan karakteristik masing-masing variabel yang diteliti dengan menggunakan distribusi frekuensi dalam ukuran persentase dan bivariat yaitu Untuk menilai hubungan antara variabel independen dengan dependen yang merupakan kategori maka uji statistik yang digunakan adalah uji chi square, pada tingkat kepercayaan 95\%, dan hubungan dikatakan bermakna apabila $\mathrm{p}$ value $\leq 0.05$ dan tidak ada hubungan yang bermakna jika $p$ value $>0.05$ (Hastono, 2001)

\section{HASIL DAN PEMBAHASAN}

Tabel 1. Distribusi frekuensi

\begin{tabular}{lcc}
\multicolumn{1}{c}{ Variabel } & Jumlah & Persentase \\
\hline $\begin{array}{l}\text { Pemberian MP ASI Dini } \\
\text { Ya }\end{array}$ & 23 & 45,1 \\
Tidak & 28 & 54,9 \\
\hline Pengetahuan Ibu & & \\
$\quad$ Tidak Baik & 25 & 49 \\
Baik & 26 & 51 \\
\hline Kecukupan ASI & & \\
Kurang & 19 & 37,3 \\
Cukup & 32 & 62,7 \\
\hline Pekerjaan & & 47,1 \\
Bekerja & 24 & 52,9 \\
Tidak Bekerja & 27 & \\
\hline Dukungan Keluarga & & 54,9 \\
Mendukung & 28 & 45,1 \\
Tidak mendukung & 23 & \\
\hline
\end{tabular}

Tabel 1. menunjukkan responden yang bayinya tidak diberikan MP-ASI dini yaitu sebanyak $28 \quad(54,9 \%)$ lebih besar dibandingkan responden yang bayinya sudah diberikan MP-ASI dini sebanyak 23 $(45,1 \%)$. Sebanya $26 \quad(51 \%)$ responden dengan kategori pengetahuan baik lebih besar dibandingkan responden dengan kategori pengetahuan tidak baik yaitu sebanyak 25 (49\%) responden. Kategori kecukupan ASI cukup lebih besar 32 (62, $7 \%$ ) responden dibandingkan responden dengan kategori kecukupan ASI kurang yaitu sebanyak $19(37,3 \%)$ responden. Kategori pekerjaan tidak bekerja lebih besar sebanyak $27 \quad(52, \quad 9 \%)$ responden 


\section{Jurnal Aisyah: Jurnal Ilmu Kesehatan 2 (2) 2017, - 144}

Eko Heryanto

dibandingkan responden dengan kategori pekerjaan bekerja yaitu sebanyak 24 (47, $1 \%)$ responden. Dan sebanyak $28(54,9 \%)$ responden dengan kategori dukungan keluarga mendukung lebih besar dibandingkan responden dengan kategori dukungan keluarga tidak mendukung.yaitu sebanyak $23(45,1 \%)$ responden

Tabel. 2. Faktor-Faktor yang Berhubungan dengan Kejadian Diare

\begin{tabular}{|c|c|c|c|c|c|c|c|}
\hline & \multicolumn{4}{|c|}{ Kejadian Diare } & \multirow{3}{*}{$\Sigma$} & \multirow{3}{*}{$\%$} & \multirow{3}{*}{ P value } \\
\hline & \multicolumn{2}{|c|}{ Ya } & \multicolumn{2}{|c|}{ Tidak } & & & \\
\hline & $\mathbf{N}$ & $\%$ & $\mathbf{N}$ & $\%$ & & & \\
\hline \multicolumn{8}{|l|}{ Pengetahuan } \\
\hline Baik & 16 & 64 & 9 & 36 & 25 & 100 & \multirow[b]{2}{*}{0,017} \\
\hline Tidak baik & 7 & 26,9 & 19 & 73,1 & 26 & 100 & \\
\hline \multicolumn{8}{|l|}{ Kecukupan ASI } \\
\hline Kurang & 17 & 89,5 & 2 & 10,5 & 19 & 100 & \multirow{2}{*}{0,000} \\
\hline Cukup & 6 & 18,8 & 26 & 81,3 & 32 & 100 & \\
\hline \multicolumn{8}{|l|}{ Pekerjaan } \\
\hline Bekerja & 17 & 70,8 & 7 & 29,2 & 24 & 100 & \multirow[b]{2}{*}{0,001} \\
\hline Tida bekerja & 6 & 22,2 & 21 & 77,8 & 27 & 100 & \\
\hline \multicolumn{8}{|l|}{ Dukungan Keluarga } \\
\hline Mendukung & 20 & 71,8 & 8 & 28,6 & 28 & 100 & \multirow{2}{*}{0,000} \\
\hline Tidak mendukung & 3 & 13 & 20 & 87 & 23 & 100 & \\
\hline
\end{tabular}

Dari tabel 2. proporsi responden dengan pengetahuan kurang yang bayinya sudah diberi MP-ASI dini sebanyak 16 (64\%) responden, lebih besar dibandingkan dengan proporsi responden dengan pengetahuan baik yang bayinya sudah diberi MP-ASI dini yaitu $7 \quad(26,9 \%)$ responden. Hasil uji statistik chi square diperoleh $p$ value 0,017 . Hal ini berarti ada hubungan yang bermakna antara pengetahuan responden dengan pemberian MP-ASI dini. Proporsi responden dengan kecukupan ASI kurang yang bayinya sudah diberi MP-ASI dini sebanyak 17 (89, 5\%) responden, lebih besar dibandingkan dengan proporsi responden dengan kecukupan ASI cukup yang bayinya sudah diberi MP-ASI dini yaitu $6 \quad(18,8 \%)$ responden. Hasil uji statistik chi square diperoleh $p$ value 0,000 . Hal ini berarti ada hubungan yang bermakna pemberian kecukupan ASI dengan pemberian MP-ASI dini.

Kategori bekerja yang bayinya sudah diberi MP-ASI dini sebanyak 17 (70, 8\%) responden, lebih besar dibandingkan dengan proporsi responden dengan kategori tidak bekerja yang bayinya sudah diberi MP-ASI dini yaitu $6(22,2 \%)$ responden. Hasil uji statistik chi square diperoleh $p$ value 0,001. Hal ini berarti ada hubungan yang bermakna antara pekerjaan responden dengan pemberian MP-ASI dini.

Proporsi responden dengan dukungan keluarga mendukung yang bayinya sudah diberi MP-ASI dini sebanyak 20 (71, 4\%) responden, lebih besar dibandingkan dengan proporsi responden dengan dukungan keluarga tidak mendukung yang bayinya sudah diberi MP-ASI dini yaitu 3 (13\%) responden. Hasil uji statistik chi square diperoleh $p$ value 0,000 . Hal ini berarti ada hubungan yang bermakna antara dukungan keluarga dengan pemberian MPASI dini.

Hubungan Pengetahuan Ibu dengan Pemberian MP-ASI Dini.

Dari hasil analisa univariat diketahui sebanyak 26 (51\%) responden dengan kategori pengetahuan baik dan sebanyak 25 (49\%) responden dengan kategori pengetahuan tidak baik. Hasil uji statistik 
diperoleh $\mathrm{p}$ value value 0,017 . Hal ini berarti bahwa ada hubungan yang bermakna antara pengetahuan responden dengan pemberian MP-ASI dini.

Pengetahuan adalah hasil penginderaan manusia, atau hasil tahu seseorang terhadap suatu objek melalui indera yang dimilikinya (mata, hidung, telinga, dan sebagainya). Dengan sendirinya, pada waktu penginderaan sampai menghasilkan pengetahuan tersebut sangat dipengaruhi oleh intensitas perhatian dan persepsi terhadap objek. Sebagian besar pengetahuan seseorang diperoleh melalui indera pendengaran (telinga), dan indera penglihatan (mata). Pengetahuan seseorang terhadap objek mempunyai intensitas atau tingkat yang berbeda-beda (Notoatmodjo, 2012).

Pengetahuan adalah kesan di dalam pikiran manusia sebagai hasil penggunaan panca inderanya. Pengetahuan juga merupakan hasil mengingat suatu hal, termasuk mengingat kembali kejadian yang pernah dialami baik secara sengaja maupun tidak disengaja dan ini terjadi setelah orang melakukan kontak atau pengamatan terhadap suatu objek tertentu (Mubarok, 2009).

Sejalan dengan hasil penelitian Kumalasari, dkk (2015) tentang faktorfaktor yang berhubungan dengan pemberian makanan pendamping ASI dini di wilayah binaan Puskesmas Sidomulyo Pekan Baru didapatkan hasil bahwa ibu yang memiliki tingkat pengetahuan dalam kategori "tidak baik" memiliki risiko sebesar 2,425 kali untuk memberikan MP-ASI dini pada bayi usia $<6$ bulan. Pengetahuan ibu yang masih kurang terhadap manfaat pemberian ASI eksklusif sangat erat kaitannya dengan pemberian MP-ASI dini.

Dalam penelitian ini menunjukkan adanya hubungan yang bermakna antara pengetahuan dengan pemberian MP-ASI, dimana ibu dengan pengetahuan yang baik cenderung tidak memberikan MP-ASI dibandingkan dengan ibu yang pengetahuannya kurang. Responden dengan pengetahuan baik, sudah memahami bahwa bayi di bawah umur 6 bulan belum boleh diberikan makanan lain selain ASI dikarenakan pencernaannya belum siap. Semakin baik pengetahuan responden maka cenderung untuk tidak memberikan MPASI dini. Namun dalam penelitian ini ditemukan juga responden dengan pengetahuan baik yang memberikan MPASI dini kepada bayinya. Dalam hal ini pengetahuan yang didapat responden hanya sebatas tahu tentang MP-ASI dini, tetapi tidak dipraktikkan dalam tindakan nyata. Ini banyak terjadi pada responden dengan usia muda yang belum mempunyai banyak pengalaman dalam merawat bayi. Meskipun mereka tahu tentang MP-ASI dini, namun dalam tindakan masih dipengaruhi orang tua yang dianggap lebih berpengalaman.

Selanjutnya berdasarkan pengakuan responden dengan kategori pengetahuan kurang alasan mereka sudah memberikan MP-ASI pada bayi sejak usia di bawah enam bulan dikarenakan kurang memahami pengetahuan tentang MP-ASI. Responden mengenalkan makanan tambahan seperti susu formula dan makanan lunak kurang dari 6 bulan agar anaknya kenyang dan tertidur pulas, jika anak diberi makan pisang sewaktu berumur 2 bulan agar anak tidak rewel dan lebih tenang, berat badan anak akan bertambah dan lebih cepat besar. Hal ini disebabkan karena ketidaktahuan ibu tentang manfaat dan cara pemberian MP-ASI yang benar dan kebiasaan pemberian MP-ASI yang tidak tepat. Hal lain yang berhubungan dengan pemberian MP-ASI dini pada bayi di Desa Negeri Agung ialah sikap ibu terhadap pemberian MP-ASI tersebut, dimana sikap ibu menganggap bahwa pemberian MP-ASI merupakan hal yang tidak perlu dikhawatirkan, dan merupakan suatu faktor kebiasaan masyarakat setempat, bahwa bayi di bawah usia enam bulan sudah bisa diberikan makanan 
pendampin MP-ASI atau menu makanan keluarga.

Oleh karena itu, apabila pengetahuan tentang pemberian MP-ASI ditingkatkan, maka kecenderungan untuk tidak memberikan MP-ASI dini pada bayi dapat juga tercapai secara optimal. Diharapkan kepada petugas kesehatan untuk meningkatkan frekuensi dan kualitas programnya melalui berbagai metode, di antaranya seperti meningkatkan pembuatan leaflet yang memuat informasi yang lengkap tentang kapan waktu yang tepat untuk memberikan MP-ASI. Tingkat keseringan mendapatkan informasi akan meningkatkan pengetahuan seluruh masyarakat.

\section{Hubungan Kecukupan ASI dengan Pemberian MP-ASI Dini}

Dari hasil analisa univariat diketahui sebanyak 32 (62,7\%) responden dengan kategori kecukupan ASI cukup dan sebanyak 19 (37,3\%) responden dengan kategori kecukupan ASI kurang. Hasil uji statistik diperoleh $p$ value 0,000 . Hal ini berarti bahwa ada hubungan yang bermakna antara kecukupan ASI dengan pemberian MP-ASI dini.

Produksi ASI adalah proses terjadinya pengeluaran air susu dimulai atau dirangsang oleh isapan mulut bayi pada puting susu ibu. Gerakan tersebut merangsang kelenjar Pictuitary Anterior untuk memproduksi sejumlah prolaktin, hormon utama yang mengandalkan pengeluaran Air Susu. Proses pengeluaran air susu juga tergantung pada Let Down Replex, dimana hisapan puting dapat merangsang kelenjar Pictuitary Posterior untuk menghasilkan hormon oksitolesin, yang dapat merangsang serabut otot halus di dalam dinding saluran susu agar membiarkan susu dapat mengalir secara lancer (Roesli, 2012).

Produksi ASI merupakan hasil perangsangan payudara oleh hormon prolaktin. Hormon ini dihasilkan oleh kelenjar hipofise anterior yang ada yang berada di dasar otak. Bila bayi mengisap ASI maka ASI akan dikeluarkan dari gudang ASI yang disebut sinus laktiferus. Proses pengisapan akan merangsang ujung saraf disekitar payudara untuk membawa pesan ke kelenjar hifofise anterior untuk memproduksi hormone prolaktin. Prolaktin kemudian akan dialirkan ke kelenjar payudara untuk merangsang pembuatan ASI. Hal ini disebut dengan refleks pembentukan ASI atau refleks prolaktin (Roesli, 2010).

Pada minggu bulan terakhir kehamilan, kelenjar-kelenjar pembuat ASI mulai menghasilkan ASI. Apabila tidak ada kelainan, pada hari pertama sejak bayi lahir akan dapat menghasilkan 50-100 ml sehari dan jumlah akan terus bertambah sehingga mencapai $400-450 \mathrm{ml}$ pada waktu mencapai usia minggu kedua. Dalam keadaan produksi ASI telah normal volume susu terbanyak yang dapat diperoleh adalah 5 menit pertama pengisapan oleh bayi biasanya berlangsung selama 15-25 menit (Hubertin, 2014).

Pada hari-hari pertama setelah kelahiran apabila bayi dibiarkan menyusu sesuai keinginannya dan tidak diberikan cairan lain maka akan dihasilkan secara bertahap 10-100 ml ASI per hari. Produksi ASI akan optimal setelah hari 10-14. Bayi sehat akan mengkonsumsi 700-800 ml ASI per hari. Setelah 6 bulan pertama produksi ASI akan menurun menjadi 400-700 $\mathrm{ml}$ sehingga diperlukan makanan pendamping ASI. Setelah 1 tahun, produksi ASI hanya sekitar 300-500 ml sehingga makanan padat menjadi makanan utama.

Ibu sebaiknya tidak menjadwalkan pemberian ASI. Menyusui paling baik dilakukan sesuai permintaan bayi (on demand) termasuk pada malam hari, minimal 8 kali per hari. Produksi ASI sangat dipengaruhi oleh seringnya bayi menyusu. Makin jarang bayi disusui biasanya produksi ASI akan berkurang (Arifin, 2011). 
Sejalan dengan hasil penelitian yang telah dilakukan oleh Sulastri (2014) di Kelurahan Sine Sragen dimana dari 80 responden terdapat $2,5 \%$ pemberian MP-ASI tepat waktu dan $97,5 \%$ pemberian MP-ASI dini. Hal ini menunjukkan bahwa produksi ASI mempengaruhi pemberian MP-ASI dini pada bayi.

Dalam penelitian ini masih ditemukan responden dengan kecukupan ASI cukup, namun sudah memberikan MP-ASI dini kepada bayinya. Hal ini disebabkan karena ibu melakukan persalinan dibantu oleh dukun bayi. Penolong persalinan non-nakes (seperti dukun beranak) menganjurkan memberikan makana lain selain ASI berupa madu dan pisang.

Sedangkan pada responden dengan kecukupan ASI kurang, menurut hasil wawancara diperoleh informasi bahwa masih ada ibu-ibu yang memberikan makanan tambahan bagi bayi di usia kurang dari 6 bulan dengan alasan karena produksi ASI kurang dan bayi menangis. Dalam pikiran ibu, bayi yang terus menangis dianggap lapar sementara ASI tidak cukup, sehingga mereka terpaksa memberikan makanan tambahan untuk memenuhi kebutuhan bayi. Jenis MP-ASI yang diberikan selain susu formula yaitu berupa pisang, bubur instant dan bubur yang dibuat sendiri. Selain itu responden juga mengungkapkan bahwa anaknya menolak untuk menyusu pada ibu karena kesulitan mencari puting ibunya, karena puting ibu yang tidak menonjol, yang membuat keluarnya ASI tidak lancar.

Untuk itu hendaknya tenaga kesehatan (bidan) diharapkan lebih sering memberikan informasi kepada ibu-ibu menyusui tentang bagaimana meningkatkan produksi ASI yaitu dengan mengkonsumsi makanan sayuran hijau seperti daun katuk, daun pepaya, bayam, buncis, jagung dan kacang. Dapat juga dengan meminum vitamin pelancar ASI, susu ibu hamil dan memperbanyak konsumsi air putih.
Hubungan Pekerjaan dengan Pemberian MP-ASI Dini.

Dari hasil analisa univariat diketahui sebanyak 27 (52,9\%) responden dengan kategori pekerjaan tidak bekerja dan sebanyak $24(47,1 \%)$ responden dengan kategori pekerjaan bekerja. Hasil uji statistik diperoleh $\mathrm{p}$ value 0,001 . Hal ini berarti bahwa ada hubungan yang bermakna antara dukungan keluarga dengan pemberian MP-ASI dini.

Pekerjaan adalah aktivitas yang dilakukan seseorang setiap hari dalam menjalani kehidupannya. Faktor pekerjaan adalah faktor yang berhubungan dengan aktivitas ibu setiap harinya untuk memperoleh penghasilan guna memenuhi kebutuhan hidupnya yang menjadi alasan pemberian makanan tambahan pada bayi usia kurang dari enam bulan. Pekerjaan ibu bisa saja dilakukan di rumah, di tempat kerja baik yang dekat maupun jauh dari rumah. Ibu yang belum bekerja sering memberikan makanan tambahan dini dengan alasan melatih atau mencoba agar pada waktu ibu mulai bekerja bayi sudah terbiasa. Status pekerjaan yang semakin baik dan sosial ekonomi keluarga yang meningkat menyebabkan ibu mudah untuk memberikan susu formula dan MP-ASI pada anak (Mubarak, 2009).

Pekerjaan merupakan kegiatan formal yang dilakukan dalam kehidupan sehari-hari yang berpengaruh terhadap orang lain dan kegiatan yang dilakukan orang tua bersifat menghasilkan uang sehingga pendapatan keluarga dapat memadai kebutuhan anak guna pertumbuhan dan perkembangan anak (Irawati, 2014).

Sejalannya dengan arus modernisasi saat ini dimana partisipasi angkatan kerja wanita, baik di sektor formal maupun informal cenderung meningkat, hal tersebut yang menjadikan salah satu kendala bagi ibu-ibu untuk memberikan ASI eksklusif. Turut sertanya ibu dalam mencari nafkah untuk memenuhi kebutuhan hidup keluarganya, 
khususnya ibu yang masih menyusui menyebabkan bayinya tidak dapat disusui dengan baik dan teratur. Hal yang membuat ibu memberhentikan pemberian ASI eksklusif adalah singkatnya masa cuti hamil/melahirkan yang mengharuskan ibu kembali bekerja sehingga mengganggu upaya pemberian ASI eksklusif selama enam bulan. Bagi ibu yang sering keluar rumah baik dikarenakan bekerja ataupun karena kegiatan sosial menjadikan ibu lebih sering memberikan susu formula dibandingkan memberikan ASI (Mulyaningsih, 2010).

Sejalan dengan hasil penelitian Pernanda (2010) tentang hubungan pekerjaan dengan MP-ASI dini, didapatkan hasil bahwa terdapat hubungan antara pekerjaan dengan pemberian MP-ASI dini dimana proporsi ibu-ibu yang bekerja sebesar $(40.2 \%)$ memiliki proporsi MP-ASI dini lebih tinggi dibandingkan proporsi ibu-ibu yang tidak bekerja $(50,9 \%)$ dengan nilai $\mathrm{p}<0,05$.

Dalam penelitian ini, umumnya responden bekerja sebagai petani dengan waktu kerja mulai dari pagi sampai tengah hari, terkadang sampai sore hari. Para ibu menyusui yang bekerja merasa sangat kesulitan membagi waktu untuk memberikan ASI secara Eksklusif kepada bayinya sehingga sebagai alternatif agar bayinya tetap terpenuhi kebutuhannya para ibu mulai memberikan MP-ASI seperti susu formula kepada bayinya ketika mereka berada di luar rumah. Padahal sebenarnya, walaupun ibu sibuk dalam pekerjaannya, pemberian ASI eksklusif kepada bayi masih bisa dilakukan yaitu dengan cara memompa atau memerah ASI dan selanjutnya ASI disimpan untuk diberikan kepada bayinya. Selain itu hal ini juga didukung dengan banyaknya iklan ditelevisi tentang susu formula yang menawarkan berbagai macam keunggulan yang dapat dirasakan pada bayi.

Sebagai solusi dari kondisi tersebut, petugas kesehatan sebaiknya memberikan konseling kepada para ibu menyusui yang bekerja tersebut untuk dapat memerah ASI kemudian menyimpannya di dalam kulkas sehingga bayinya tetap mendapatkan ASI eksklusif walaupun ibu sedang tidak berada di samping sang bayi. Jadi, alasan ibu bekerja bukan merupakan alasan untuk ibu memberikan MP-ASI dini kepada bayinya.

\section{Hubungan Dukungan Keluarga dengan Pemberian MP-ASI.}

Dari hasil analisa diketahui sebanyak 28 $(54,9 \%)$ responden dengan kategori dukungan keluarga mendukung dan sebanyak $24(45,1 \%)$ responden dengan kategori dukungan keluarga tidak mendukung. Hasil uji statistik diperoleh $\mathrm{p}$ value 0,000 . Hal ini berarti bahwa ada hubungan yang bermakna antara dukungan keluarga dengan pemberian MP-ASI dini.

Sesuai teori Bussard dan Ball (1966) dalam Friedman (2010) keluarga merupakan lingkungan sosial yang sangat dekat hubungannya dengan seseorang. Di keluarga itu seseorang dibesarkan, bertempat tinggal, berinteraksi satu dengan yang lain, dibentuknya nilai-nilai, pola pemikiran, dan kebiasannya dan berfungsi sebagai saksi segenap budaya luar, dan mediasi hubungan anak dengan lingkungannya.

Dukungan keluarga merupakan suatu proses yang terjadi sepanjang masa kehidupan, sifat dan jenis dukungan berbeda-beda pada setiap tahap siklus kehidupan. Setiap anggota keluarga mempunyai struktur peran formal dan informal, misalnya ayah mempunyai peran formal sebagai kepala keluarga dan pencari nafkah. Peran informal ayah adalah sebagai panutan dan pelindung keluarga. Struktur keluarga meliputi kemampuan berkomunikasi, kemampuan keluarga saling berbagi, kemampuan sistem pendukung di antara anggota keluarga, kemampuan perawatan diri dan kemampuan menyelesaikan masalah. Menurut Bugges dalam Friedman (2004) keluarga terdiri dari orang-orang yang disatukan oleh ikatan perkawinan, darah dan ikatan adopsi. Para 
anggota sebuah keluarga biasanya hidup bersama-sama dalam satu rumah tangga, atau jika mereka hidup secara terpisah, mereka tetap menganggap rumah tangga tersebut sebagai rumah mereka. Anggota keluarga berinteraksi dan berkomunikasi satu sama lain dalam peran-peran sosial keluarga seperti suami isteri, ayah dan ibu, anak laki-laki (Firedman, 2010).

Keluarga memiliki fungsi dukungan yaitu dukungan informasional, dukungan penilaian, dukungan isntrumental dan dukungan emosional. Dukungan informasional adalah keluarga berfungsi sebagai sebuah keluarga diseminator atau penyebar informasi tentang semua informasi yang ada dalam kehidupan. Keluarga berfungsi sebagai pencari informasi yang berhubungan dengan masalah menyusui dari tenaga kesehatan, dan melakukan konsultasi, serta mencari informasi dari media cetak maupun sumber lain yang mendukung. Dukungan penilaian adalah jenis dukungan dimana keluarga bertindak sebagai pembimbing dan bimbingan umpan balik, memecahkan masalah dan sebagai sumber validator identitas anggota dalam keluarga. Dukungan instrumental adalah bentuk dukungan dimana keluarga sebagai sebuah sumber petolongan praktis dan kongkrit untuk menyelesaikan masalah, dan dukungan emosional adalah bentuk dukungan dimana keluarga sebagai sebuah tempat pemulihan yang aman dan damai untuk beristirahat dan membantu secara psikologis untuk menstabilkan emosi dan mengendalikan diri. Salah satu bentuknya adalah melalui pemberian motivasi dan sebagai fasilitator serta mendengarkan seluruh keluhan-keluhan anggota keluarga atau ibu terhadap masalah yang sedang dihadapinya (Firedman, 2010).

Sesuai dengan hasil penelitian Tiasna (2015) dengan judul hubungan dukungan keluarga dengan pemberian MP-ASI dini di Puskesmas Sewon 1 Bantul diperoleh analisis Chi Square antara variabel bebas (dukungan keluarga) dengan variabel terikat(pemberian MP-ASI dini) dengan nilai signifikan $\mathrm{P}$ Value sebesar 0,012 , hal ini menunjukkan ada hubungan antara dukungan keluarga dengan pemberian MPASI dini karena $p$ value $<\alpha(0,012<0,05)$. Hal ini dapat diartikan, jika seseorang tidak mempunyai dukungan dari keluarganya untuk memberikan ASI eksklusif maka akan meningkatkan pemberian MP-ASI dini pada bayi.

Dukungan keluarga mempunyai hubungan yang signifikan dengan pemberian makanan pendamping ASI. Dukungan keluarga yang tinggi terhadap pemberian makanan pendamping ASI menimbulkan efek negatif terhadap kesehatan bayi. Hal ini jelas bahwa jika keluarga memberikan peran atau dukungan yang baik akan mendorong ibu untuk tidak memberikan makanan pendamping ASI kepada bayi mereka saat usia 0-6 bulan, untuk itu informasi tentang MP-ASI bukan hanya diberikan kepada ibuibu saja tetapi suami dan keluarga, sehingga mereka juga memperoleh pengetahuan tentang MP-ASI dan membantu untuk mencegah atau mendukung ibu untuk tidak memberikan MP-ASI secara dini.

Menurut asumsi peneliti, masih ada dijumpai ibu-ibu yang mempunyai bayi yang memberikan MP-ASI terlalu dini, dikarenakan adanya pengaruh yang lebih kuat, yaitu anjuran keluarga terdekat, misalnya suami/orang tua. Mayoritas responden mengaku pernah mendapatkan anjuran untuk memberikan susu formula dan MP-ASI dini pada masa pemberian ASI eksklusif. Dukungan suami ataupun keluarga sangat besar pengaruhnya, seorang ibu yang mendapatkan dukungan oleh suami ataupun anggota keluarga lainnya atau bahkan menakut-nakuti tentang mitos bahwa bayinya akan merasa kelaparan jika hanya diberikan ASI saja, hal tersebut akan mengganggu psikologis ibu dan bahwa membuat ibu merasa cemas akan kondisi bayinya dan membuat ibu untuk berfikir 
memberikan tambahan susu formula/MPASI dini untuk sang bayi.

Petugas kesehatan hendaknya memotivasi keluarga untuk meningkatkan perhatian kepada ibu menyusui terhadap pemberian ASI ekslusif pada bayi. Hal ini disebabkan pentingnya ASI ekslusif bagi bayi. Langkah-langkah yang dapat dilakukan oleh petugas kesehatan misalnya dengan memberikan penyuluhan atau pendidikan kesehatan kepada masyarakat.

\section{KESIMPULAN DAN SARAN}

Berdasarkan hasil penelitian dapat disimpulkan bahwa terdapat hubungan yang bermakna antara pemberian MPASI dini dengan pengetahuan ( $p$ value 0,017), kecukupan ASI ( $p$ value 0,000$)$, pekerjaan ( $p$ value 0,001$)$ dan dukungan keluarga $(p$ value 0,000) di Desa Negeri Agung Wilayah Kerja UPTD Puskesmas Buay Sandang Aji Kabupaten OKU Selatan.

Diharapkan kepada petugas kesehatan untuk meningkatkan frekuensi dan kualitas programnya melalui pembuatan leaflet yang memuat informasi lengkap tentang kapan waktu yang tepat untuk memberikan MPASI. Tenaga kesehatan (bidan) diharapkan lebih sering memberikan informasi kepada ibu-ibu menyusui tentang bagaimana meningkatkan produksi ASI yaitu dengan mengkonsumsi makanan sayuran hijau seperti daun katuk, daun pepaya, bayam, buncis, jagung dan kacang. Dapat juga dengan meminum vitamin pelancar ASI, susu ibu hamil dan memperbanyak konsumsi air putih. Petugas kesehatan sebaiknya memberikan konseling kepada para ibu menyusui yang bekerja tersebut untuk dapat memerah ASI kemudian menyimpannya di dalam kulkas sehingga bayinya tetap mendapatkan ASI eksklusif walaupun ibu sedang tidak berada di samping sang bayi. Petugas kesehatan hendaknya memotivasi keluarga untuk meningkatkan perhatian kepada ibu menyusui terhadap pemberian ASI ekslusif pada bayi. Hal ini disebabkan pentingnya ASI ekslusif bagi bayi. Langkah-langkah yang dapat dilakukan oleh petugas kesehatan misalnya dengan memberikan penyuluhan atau pendidikan kesehatan kepada masyarakat. 


\section{Jurnal Aisyah: Jurnal Ilmu Kesehatan 2 (2) 2017, - 151}

Eko Heryanto

\section{DAFTAR PUSTAKA}

Arifin, Siregar. (2011). Pemberian ASI Eksklusif dan Faktor-faktor yang Mempengaruhinya. Sumatra Utara: Universitas Sumatra Utara.

Dadiyanto, WD, dkk. (2012). Simposium dan Workshop: Nutrisi dan Metabolik, Endokrinologi, Nefrologi dan Neurologi. IDAI Cabang Jawa Tengah: IKA FK Undip.

Depkes RI. (2010). Pedoman Umum Pemberian Makanan Pendamping Air Susu Ibu (MPASI) Lokal. Jakarta: Departemen Kesehatan Republik Indonesia.

. (2012). Indonesia Menyusui: sepuluh langkah menuju sayang bayi. Jakarta: Departemen Kesehatan Republik Indonesia.

. (2013). Makanan Pendamping ASI (MP-ASI). Jakarta: Direktorat Bina Gizi Masyarakat.

Friedman. (2010). Keperawatan Keluarga. Jakarta: EGC.

Hastono Sutanto Priyo. (2001). Modul Analisis Data. Jakarta: Fakultas Kesehatan Masyarakat Universitas Indonesia.

Hubertin S. (2014). Konsep Penerapan ASI Eksklusif: Buku Saku Untuk Bidan. Jakarta: EGC.

Husaini, M. (2011). Makanan Bayi Bergizi. Cetakan VIII. Yogyakarta: Gajah Mada University Press.

Irawati, A. (2014). Stop Makanan Pendamping ASI Terlalu Dini. http://www.ayahbunda.co.id/Artikel/ Gizi+dan+Kesehatan/stop.makanan. pendamping.asi.terlalu.dini/001/001/ 546/7/makan/4. (Diakses, 23 Maret 2017).

Khomsan, Ali. (2008). Sehat dengan Makanan Berkhasiat. Editor: Irwan Suhanda. Jakarta: Kompas Gramedia.

Krisnatuti, D. \& Yenrina, R. (2013). Menyiapkan Makanan Pendamping ASI. Jakarta: Puspa Swara.

Kristianto, Yonatan. (2012). Faktor yang Mempengaruhi Perilaku Ibu dalam Pemberian Makanan Pendamping ASI Pada Bayi Umur 6 - 36 Bulan. Jurnal STIKES. Volume 6, No. 1, Juli 2013.

Kumalasari. (2015). Faktor-Faktor Yang Berhubungan Dengan Pemberian Makanan Pendamping ASI Dini. Riau: Universitas Riau.

Mulyaningsih F. (2010). Hubungan antara Pengetahuan Ibu Tentang Gizi Balita dan Pola Makan Balita Terhadap Status Gizi Balita di Kelurahan Srihardono Kecamatan Pundong. Skripsi (Tidak Diterbitkan). Yogyakarta: Fakultas Teknik Universitas Negeri Yogyakarta.

Mubarak Wahid Iqbal. (2009). Ilmu Kesehatan Masyarakat. Teori dan Aplikasi. Jakarta: Salemba Medika.

Notoatmodjo Soekidjo. (2010). Metodologi Penelitian Kesehatan. Jakarta: Rineka Cipta.

. (2012). Pendidikan dan Perilaku Kesehatan, Rineka Cipta, Jakarta.

. (2012). Prinsi-Prinsip Dasar Ilmu Kesehatan Masyarakat. Jakarta: Rineka Cipta.

Pernanda. (2010). Faktor-Faktor yang mempengaruhi Ibu dalam 
Pemberian Makanan MP-ASI Dini pada Bayi 6-24 Bulan di Kelurahan Pematang Kandis Bangko, Kabupaten Merangin Jambi Tahun 2010. Karya Tulis Ilmiah. Sumatera Utara: FK USU.

Riksani, R. (2012). Variasi Olahan Makanan Pendamping ASI. Jakarta: Dunia Kreasi.

Roesli, Utami. (2010). Bayi Sehat Berkat ASI Eksklusif. Jakarta: PT Elex Komputindo.

. (2012). Spesifikasi Teknis Makanan Pendamping Air Susu Ibu (MP-ASI). Jakarta: PT Elex Komputindo.

Rosmalia Helmi \& Mindo Lupiana. (2011). Faktor-Faktor Yang Berhubungan Dengan Status Gizi Pada Balita Di Wilayah Kerja Puskesmas Margototo Kecamatan Metro Kibang Kabupaten Lampung Timur. Skripsi.

Riset Kesehatan Dasar (Riskesdas). (2013). Badan Penelitian dan Pengembangan Kesehatan Kementerian RI tahun 2013. Jakarta.

Setiawan, Albertus. (2009). Pemberian Makanan Pendamping ASI dan hubungannya dengan Infeksi pada Bayi 0-6 bulan di Puskesmas Cipayung, Kota Depok tahun 2009. Skripsi.

Simanjuntak, E. (2010). Gambaran Pengetahuan Ibu Tentang Pola Pemberian ASI, MP-ASI dan Pola Penyakit. Skripsi. Tidak Diterbitkan. Medan. Universitas Sumatera Utara.

Suharyono. (2011). ASI Tinjauan dari Beberapa Aspek. Jakarta: Fakultas Kedokteran Universitas Indonesia.
Sulastri. (2014). Hubungan antara Pemberian Makanan Tambahan pada Usia Dini dengan Tingkat Kunjungan ke Pelayanan Kesehatan di Kelurahan Sine Sragen. Vol. 1 (3): 113-118.

Tiasna Apriani. (2015). Hubungan Dukungan Keluarga dengan Pemberian MP-ASI Dini di Puskesmas Sewon 1 Bantul. Skripsi. Tidak diterbitkan. Jogjakarta.

Utami. (2012). Buku Pintar ASI Eksklusif. Yogyakarta: Diva Press.

Widodo, Triwinarto. (2012). ASI Eksklusif, Status Kini dan Harapan di Masa Pemantauan Kantin Perusahaan. Jakarta. 